\title{
A FUNÇÃO REVISORA DOS TRIBUNAIS NA PERSPECTIVA HISTÓRICA E JUSFUNDAMENTAL: O DIREITO DE RECORRER. ORIGENS E LIMITES EXTERNOS
}

\author{
THE REVIEWING FUNCTION OF COURTS IN HISTORICAL AND JUSFUNDAMENTAL \\ PERSPECTIVES: THE RIGHT TO APPEAL. ITS ORIGIN AND EXTERNAL LIMITS
}

Guilherme Guimarães Feliciano*

\begin{abstract}
Resumo:
$\mathrm{O}$ artigo investiga as origens históricas do duplo grau de jurisdição, de Roma ao Estado Moderno, e a partir desse escorço examina se o direito de recorrer pode ser admitido, hoje, como um direito humano fundamental de caráter universal. Propõe especialmente uma revisão crítica do modelo recursal que se estabeleceu no processo do trabalho, encaminhando as bases ideais de uma reforma que prestigie as decisões de primeiro grau, quanto às questões de fato.

Palavras-chave: Direito ao recurso. Direitos humanos fundamentais. Processo do trabalho.
\end{abstract}

\begin{abstract}
:
This paper investigates the historical origins of the right of appeal since Rome until the modern State, and examines whether the right of appeal could be admitted today as a fundamental human right. It also proposes a critical review of the appeal model established in the Labor Procedure Law, forwarding the ideal basis for a reform that valuates the first-degree decisions, in case of matter of fact.
\end{abstract}

Keywords: Right of appeal. Fundamental human rights. Labor Procedure Law.

1. Convencimento judicial, direito de recorrer e magistratura profissional: ideias historicamente imbricadas. Origens históricas e reflexões possíveis

\subsection{Roma pós-clássica}

$\mathrm{Na}$ Roma cristã, depois da conhecida "litis contestatio", havia o "iusiurandum calumniae”, ato em que partes e advogados juravam, sobre as Escrituras, que não estavam litigando por mera chicana ou emulação, mas por acreditarem em suas

\footnotetext{
O Autor é Professor Associado II do Departamento de Direito do Trabalho e da Seguridade Social da Faculdade de Direito da Universidade de São Paulo e Juiz Titular da $1^{\text {a }}$ Vara do Trabalho de Taubaté/SP. Livre-Docente em Direito do Trabalho pela FDUSP. Doutor em Direito Processual Civil pela Faculdade de Direito da Universidade de Lisboa. Doutor em Direito Penal pela FDUSP. Coordenador da Pós-Graduação "stricto sensu" em Direito e Processo do Trabalho da Universidade de Taubaté.
} 
teses. Denota-se a preocupação pós-clássica com a lealdade processual, que ganharia corpo nos séculos subsequentes.

Após o "iusiurandum calumniae”, há certa dúvida sobre o que se seguia. Alguns romanistas sustentam que havia a imediata colheita de provas (fase instrutória), ${ }^{1}$ outros sustentam que, entre o "iusiurandum calumniae" e a produção de provas, mediava uma nova sessão de debates orais, a discutir os aspectos jurídicos do litígio, em que se contrapunha a "postulatio simplex" (pelo autor) e a "contradictio" ou "responsio" (pelo réu). ${ }^{2}$

Na instrução, as “leges” (= constituições imperiais) passaram a estabelecer certas regras para a apreciação das provas, a ponto de hierarquizá-las em valores absolutos. Assim é que a prova testemunhal, que tinha papel destacado no processo formulário, tem sua relevância mitigada, tanto pela regra da pluralidade útil (celebrizada pela máxima latina "testis unus, testis nullus”) como pela regra da primazia documental (prova escrita não podia ser repelida por prova testemunhal). No direito pós-clássico, com a Novela $X C$, Justiniano introduziria ainda a figura do compromisso testemunhal por juramento (o que significava tanto reconhecer o dever cívico de depor em juízo quanto o dever processual de afirmar a verdade, aprofundando o caráter publicístico do processo com o reconhecimento de efeitos jurídicos instrumentais sobre terceiros) e a regra da melhor prova pelo menor interesse (germinando a figura da suspeição por interesse no litígio). Em contrapartida, a prova documental conheceu uma importância sem precedentes no processo "extra ordinem", firmando-se no topo da hierarquia legal das provas, com uma sub-hierarquia interna que até hoje encontra eco nos ordenamentos de base romanogermânica. ${ }^{3}$ Empregavam-se, ainda, como provas, as perícias (sobretudo para a aferição da autenticidade de documentos, mas também para outras "especialidades", como no caso das "comadres", que aferiam o alegado estado gravídico de uma mulher), os

Esta parece ser a opinião de KASER, Max; HACKL, Karl. Das Römische Zivilprozessrecht. 2. Aufl. München: C. H. Beck, 1996. p. 490-491.

2 ALVES, José Carlos Moreira. Direito romano. 7. ed. Rio de Janeiro: Forense, 1991. v. 1. p. 312.

3 Em primeiro lugar, os documentos públicos lavrados por funcionários no exercício de suas funções e os protocolos de juízes e certos agentes administrativos, todos dotados de fé pública (ditos "acta" ou "gesta"); na sequência, os "instrumenta publice confecta", i.e., os documentos públicos redigidos em praça pública pelos notários ou "tabelliones" (que já àquela época não eram funcionários de Roma, mas pessoas privadas que gozavam de fé pública e certificavam atos e fatos jurídicos sob a vigilância dos magistrados; numa expressão conhecida, administração privada de interesses públicos em matéria notarial, como ainda hoje ocorre em diversos países, inclusive no Brasil); e, por fim, os instrumentos privados ("cautiones", "chirographa"), cujo valor dependia da respectiva lavratura perante testemunhas instrumentais, com as assinaturas dos declarantes e das próprias testemunhas. Cf., por todos, ALVES, José Carlos Moreira. Direito romano. 7. ed. Rio de Janeiro: Forense, 1991. v. 1. p. 313. Essa hierarquia segue reverenciada no tempo presente, com maior ou menor flexibilidade, ora por força de lei (como no caso português, nos termos do art. $364^{\circ}, 1$, do CC, e também no brasileiro, a se cotejarem os arts. 364 e 368 do CPC ou os arts. 215 e 219 do NCC), ora por força do costume e/ou da prática social. 
juramentos (como provas supletórias), as confissões (que serviam como causa bastante para a condenação do confesso, positivando-se a parêmia "confessus por iudicato est" no Corpus Iuris Civilis), os interrogatórios em juízo (admitidos em qualquer tipo de ação — ao contrário do processo formulário - e a qualquer momento do processo, ao alvedrio do juiz) e as presunções (dita "hominis", quando o juiz a extraía dos elementos do processo com base em sua experiência pessoal; "iuris", quando decorria de lei). ${ }^{4}$

Dessume-se, por esse breve descritivo, que boa parte das regras e institutos de direito probatório recolhidos pelos códigos hodiernos remontam, direta ou indiretamente, à “cognitio extraordinaria” romana. Daí também provieram variegadas restrições formais ao livre convencimento do magistrado em face do conjunto de provas, que o processo medieval aprofundou e que se retratam ainda hoje em doutrinas e legislações (em especial no quesito da hierarquização dos meios de prova, quando, p. ex., distinguese entre prova pleníssima, prova plena e prova bastante, ${ }^{5}$ ou quando se veda determinado meio de prova em certos ensejos ${ }^{6}$ ). $\mathrm{Na}$ perspectiva da teoria processual moderna (que advoga o livre convencimento racional do juiz ${ }^{7}$ ), houve inclusive um retrocesso em

4 Sobre o regime probatório na “extraordinaria cognitio", ver KASER, Max; HACKL, Karl. Das Römische Zivilprozessrecht. 2. Aufl. München: C. H. Beck, 1996. p. 491-493; ALVES, José Carlos Moreira. Direito romano. 7. ed. Rio de Janeiro: Forense, 1991. v. 1. p. 312-314.

5 Cara ao direito português - ou ao menos a seu passado próximo -, como se lê em MENDES, João de Castro. Direito processual civil. Lisboa: AAFDL, 1987. v. 2. p. 451-453. A expressão "prova plena" ainda aparece nos arts. $360^{\circ}, 371^{\circ}, 376^{\circ}$ e $393^{\circ}$ do Código Civil português; e, no Brasil, descobre-se hoje em dia no art. 215 do NCC ("A escritura pública, lavrada em notas de tabelião, é documento dotado de fé pública, fazendo prova plena”).

6 No Brasil, vejam-se, p. ex., o art. 401 do CPC (que só permite a prova exclusivamente testemunhal "nos contratos cujo valor não exceda o décuplo do maior salário mínimo vigente no país, ao tempo em que foram celebrados") e o art. 55, § $3^{\circ}$, da Lei n. 8.213/91 (que não admite, em sede de justificação judicial ou administrativa, a prova exclusivamente testemunhal do tempo de serviço para efeitos previdenciários). Sobre a infelicidade dessa última norma, especialmente quando oposta à eficácia material preclusiva das sentenças trabalhistas que declaram a existência de vínculo de emprego em face do empregador (e ainda mais à sua eficácia mandamental direta, se o INSS for chamado à lide), veja-se, de nossa lavra, FELICIANO, Guilherme Guimarães. Eficácia mandamental da sentença declaratória de vínculo empregatício em face do Instituto Nacional do Seguro Social. In: $14^{\circ}$ Congresso Nacional dos Magistrados da Justiça do Trabalho: CONAMAT, Manaus, 2008. Disponível em: <http://www.conamat.com.br/teses/10032008204910.doc>. Acesso em: 6 jan. 2016. V. também . Tutela processual dos direitos humanos nas relações de trabalho. Revista de Direito do Trabalho, São Paulo, v. 32. n. 121, p. 1-2, 2006. p. 121, passim.

7 Cf., por todos, CINTRA, Antônio Carlos de Araújo; GRINOVER, Ada Pellegrini; DINAMARCO, Cândido Rangel. Teoria geral do processo. 3. ed. rev. e atual. São Paulo: Malheiros, 1993. p. 62-63 (os autores preferem a expressão "persuasão racional"). In verbis: "Tal princípio [da persuasão racional do juiz] regula a apreciação e a avaliação das provas existentes nos autos, indicando que o juiz deve formar livremente sua convicção. Situa-se entre o sistema da prova legal e o do julgamento secundum conscientiam. [...] A partir do século XVI [...] começou a delinear-se o sistema intermediário do livre convencimento do juiz, ou da persuasão racional, que se consolidou sobretudo com a Revolução Francesa. [...] O Brasil também adota o princípio da persuasão racional: o juiz não é desvinculado da prova e dos elementos existentes nos autos (quod on est in actis non est in mundo), mas a sua apreciação não depende de critérios legais determinados a priori. $O$ juiz só decide com base nos elementos existentes no processo, mas o avalia segundo critérios críticos e racionais (CPC, arts. 131 a 436; CPP, arts. 157 e 182)" (g. n.). Nada obstante, 
relação ao sistema processual anterior ( "per formulas”), onde essas hierarquizações não se estabeleciam com tamanho vigor. E de involução, realmente, impõe-se dizer. Segundo cremos, pensar a modernização da processualística é pensar a necessária relativização de tais hierarquizações, senão a sua abolição, privilegiando-se sempre a justiça do caso concreto pelo olhar do juiz concreto. O que significa, necessariamente, prestigiar a decisão do juiz de primeiro grau nas chamadas questões de fato.

Feita a colheita de provas, o magistrado romano passava à prolação da sentença, sempre conforme os elementos dos autos. Para tanto, consultava seus assessores ( “consilium”) e, vinculando-se apenas à observância da lei (e não mais aos limites de uma fórmula), proferia a sua sentença, em peça escrita, que havia de ser lida em audiência na presença das partes e dos oficiais do juízo ("recitare sententiam ex periculo"). Mesmo perante o "princeps", o procedimento era basicamente esse, com pequenas variações. ${ }^{8}$

Excepcionalmente, porém, caso não soubesse como julgar a causa, o magistrado poderia remeter os autos a um magistrado superior ou mesmo ao próprio imperador: era o instituto da "consultatio", que prevenia, no processo "extra ordinem", o pronunciamento do "non liquet" (que, aliás, era largamente admitido no sistema formulário, anterior ao da "extra ordinem”). Nessa hipótese, o juiz redigiria uma informação geral sobre o processo e exporia suas dúvidas, dando ciência às partes, que poderiam refutar a informação judicial; em seguida, remeteria à autoridade superior o conjunto de peças (autos do processo, “consultatio” e refutação). De posse das peças, a autoridade superior decidiria o litígio (ou, tratando-se do imperador, poderia designar outro juiz para a prolação da sentença).

Na sentença, o juiz deveria condenar ou absolver o réu, assim como o próprio autor, se houvesse reconvenção formal. A condenação havia de ajustar-se o mais possível à pretensão do autor, mandando pagar a quantia devida ou restituir a coisa retida, conforme o caso. Nas obrigações de fazer, não se admitia a condenação específica (i.e., o decreto condenatório impositivo de conduta "manu militari”); assim, tanto nesses casos, como nos casos de impossibilidade de restituição de coisa certa, proferia-se sentença condenatória pelo equivalente pecuniário ao ato ou à coisa. Ademais, embora o juiz devesse considerar, em princípio, o “status quo" aferido no momento da citação do réu, deveria levar em conta a satisfação espontânea da pretensão autoral pelo réu no curso do processo, hipótese em que proferiria sentença absolutória.

não é incomum que, em algum momento, os sistemas processuais nacionais hodiernos concedam, pontual ou setorialmente, ao sistema das provas legais (em Portugal, veja-se o art. 393 1 e 2, do CC; no Brasil, vejam-se o art. 401 do CPC — já citado - e o art. 195, caput e $\S 2^{\circ}$, da CLT).

8 Inclusive na "supplicatio": ver KASER, Max; HACKL, Karl. Das Römische Zivilprozessrecht. 2. Aufl. München: C. H. Beck, 1996. p. 449. 


\section{Proferido o "decretum" ou "sententia", o vencido podia apelar}

(“appellatio"), fosse para o magistrado imediatamente superior ao que a houvera pronunciado, fosse mesmo para o imperador, diretamente, a depender da hipótese. ${ }^{9} \mathrm{De}$ fato, tornou-se bem amplo o espaço útil de recorribilidade no processo "extra ordinem": com Justiniano, já se podia apelar de qualquer sentença, desde que definitiva ou terminativa (jamais das interlocutórias ou preparatórias). Foi o mesmo Justiniano, ademais, quem limitou a duas as possíveis "appellationes" sucessivas; antes dele, podia-se apelar tantas vezes quantos fossem os magistrados escalonados entre o juiz sentenciante e o próprio imperador (a quem se dirigiria o derradeiro recurso). A “appellatio” podia ser ofertada de viva voz, na própria audiência em que se lia a sentença, ou por escrito ("libellus appellatorius"), em prazos que variaram de dois ("biduum") ou três ("triduum") a dez dias. ${ }^{10}$ Surtia, sempre, os efeitos devolutivo e suspensivo. Acompanhavam-lhe, porém, riscos consideráveis: o apelante derrotado suportava as custas acrescidas e, para mais, sujeitava-se a sanções graves, que chegaram ao desterro por dois anos, ao confisco de metade dos bens presentes e à obrigação mesma de prestar trabalhos forçados em minas por dois anos. ${ }^{11} / 12$ Já por isso, conclui-se que sequer na "extraordinaria cognitio" o duplo grau de jurisdição chegou a ser visto como uma garantia civil do cidadão; era, antes, uma faculdade processual, que o vexava severamente em caso de emprego temerário.

$9 \quad$ Na perspectiva do poder político, a lógica desse sistema de revisão escalonada - que a partir de então ganharia o mundo - transparece evidente em Kaser e Hackl: "Die Anfänge der Appellation werden bei der gegen Urteile der cognitio extra ordinem in Straf- und Zivilsachen zu suchen sein. Im Kognitionsverfahren ist alle Entscheidungsgewalt eine von der kaiserlichen delegierte, hier wird sich darum zuerst der Grundsatz entwickelt und durchgesetzt haben, daß gegen die Entscheidung des Delegiert an den Delegierenden appelliert werden kann" (KASER, Max; HACKL, Karl. Das Römische Zivilprozessrecht. 2. Aufl. München: C. H. Beck, 1996. p. 502-503). Preservaram-se, ademais, alguns dos mecanismos indiretos de impugnação de sentenças do período formulário - nomeadamente, a "restitutio in integrum" (cf. KASER, Max; HACKL, Karl. Das Römische Zivilprozessrecht. 2. Aufl. München: C. H. Beck, 1996. p. 493; TUCCI, José Rogério Cruz e; AZEVEDO, Luiz Carlos de. Lições de história do processo civil romano. São Paulo: Revista dos Tribunais, 2001. p. 150).

10 KASER, Max; HACKL, Karl. Das Römische Zivilprozessrecht. 2. Aufl. München: C. H. Beck, 1996. p. 507-508; ALVES, José Carlos Moreira. Direito romano. 7. ed. Rio de Janeiro: Forense, 1991. v. 1. p. 316317.

11 ALVES, José Carlos Moreira. Direito romano. 7. ed. Rio de Janeiro: Forense, 1991. v. 1. p. 317. No tempo de Justiniano, tais sanções se abrandaram.

12 Para uma visão geral dos institutos da "appellatio" e da "supplicatio" no Direito Romano, ver TUCCI, José Rogério Cruz e; AZEVEDO, Luiz Carlos de. Lições de história do processo civil romano. São Paulo: Revista dos Tribunais, 2001. p. 163-188. A propósito, a "supplicatio" apareceu como "corolário lógico da inadmissão de interpor-se apelação da sentença prolatada pelo prefeito do pretório" (i.e., do "praefectus praetorio", altíssimo funcionário da administração romana, que funcionava à maneira de um alter ego do imperador), razão pela qual se instituiu a "supplicatio", que serviria como "recurso autônomo e extraordinário, sucedâneo da appellatio, utilizado pelo cidadão perante o foro imperial contra a sentença inapelável do praefectus praetorio” (idem, p. 175-177). Ver também KASER, Max; HACKL, Karl. Das Römische Zivilprozessrecht. 2. Aufl. München: C. H. Beck, 1996. p. 449-451. 
Antes do julgamento da "appellatio", havia novo comparecimento das partes à presença do magistrado superior, com renovação dos debates. Sob Justiniano, admitia-se a própria reabertura da instrução probatória, como ainda a invocação de novos fatos. E, ao julgar a apelação, o juiz “ad quem” podia fazê-lo em prejuízo do recorrente, admitindo-se amplamente a "reformatio in pejus". Confirmada a sentença condenatória, e uma vez passada em julgado, havia de ser cumprida pelo réu no "tempus iudicati”, i.e., no prazo máximo de dois meses (ou, sob Justiniano, quatro meses), caso não se fixasse outro no texto do próprio "decretum".

\subsection{Direito canônico}

O processo canônico prestou grande contribuição às ideias cultas em torno da estabilização e da recorribilidade das sentenças judiciais, contribuindo sobretudo para a evolução do instituto da coisa julgada. Se bem que de início o direito canônico se tenha inspirado no próprio regime romano da coisa julgada, desenvolveu-o posteriormente com variegados elementos próprios, que mais tarde influenciariam o próprio direito leigo. $\mathrm{O}$ diploma mais relevante nessa repaginação semântica é o Decreto Graciano, que acolheu a noção romana de coisa julgada, mas alterou significativamente o seu regime, além de realçar, paralelamente, instrumentos reativos como a "restitutio in integrum" e a própria “appellatio", então considerados os dois únicos meios de impugnação de sentenças válidas, mas iníquas.

Nesse sentido é que, no desenvolvimento das suas trinta e seis "causae", o Decreto Graciano possuía inúmeros preceitos a respaldar tanto hipóteses de apelação como de "restitutio", na linha do que hoje denominamos, genericamente, como direito de revisão judicial. A “appellatio”, porém, foi objeto específico da Quaestio VI da Causa II, enquanto a "restitutio" não teve ali regulamentação específica, sendo antes referida em diversas passagens como instituto geral de caráter extraordinário. Ulteriormente, $\mathrm{o}$ seu primeiro tratamento específico e ordenado apareceria na "Libellus Ordinis Iudiciarii" (Livro IV, Título 6), de Tancredo (1214-1216), autorizando a anulação e a renovação do juízo canônico: "Sententia per beneficium in integrum restitutionis sublevatur ac scinditur et iudicium renovatur”. Da mesma forma, nas Decretais de Gregório IX (1234), a "integrum restitutione” é tratada no Título XLI do Livro I e também no Capítulo XI do Título XIII do Livro III. Ainda nos dias de hoje, a "restitutio in integrum” segue prevista no Código de Direito Canônico em vigor (c. 1645), como uma via rescisória extraordinária, para a impugnação de decisões transitadas em julgado (em casos de "manifesta injustiça", nos termos do par. $2^{\circ}$ ), a par da possibilidade do exercício das competências correicionais do Supremo Tribunal da Assinatura Apostólica nos teratológicos casos de "querelas nullitatis" (c. 1445, § $\left.1^{\circ}, 1\right)$. 
Nos tempos de Graciano, porém, não se distinguia claramente entre a coisa julgada (como atributo ou predicado) e a própria sentença judicial (como objeto a que se poderia associar aquele atributo), tendo-a como mera "definição judicial" da própria sentença. Somente décadas mais tarde, com a elaboração teórica dos glosadores (a partir dos textos romanos) e o contributo de algumas decretais papais, consolidou-se o entendimento de que o "transitus in rem iudicatam" era mesmo um predicamento de certa sentença, consistente na sua irrevogabilidade ordinária e inconfundível com a própria sentença. Reconhecia-se com isso, "a contrario sensu”, haver sentenças circunstancial e/ou naturalmente mutáveis (ao lado daquelas imutáveis, porque trânsitas em julgado), embora já definitivas; o que significou, no campo das garantias processuais, acenar, por um lado, para o reconhecimento de sentenças imanentemente mutáveis (informadas por cláusula "rebus sic stantibus"); e, por outro, para a admissão da revisão dos julgados - e, logo, do duplo grau de jurisdição - como um incipiente direito dos súditos. Para alguns autores, essa foi a maior contribuição do direito canônico para o instituto da coisa julgada, atinando-se, a partir de então, para o momento cronológico em que as sentenças formalmente adquiririam a imutabilidade da coisa julgada, "si et quando" fossem compatíveis com essa imutabilidade.

Assim é que, quanto às sentenças imanentemente mutáveis, a decretal "Lator praesentium sua nobis", do Papa Alexandre III (1159-1181), expressamente enunciou o princípio de que o "transitus in rem iudicatum" não se dava em sentenças exaradas nas ações de estado, inclusive por razões de fundo espiritual. Ainda hoje, no Código de Direito Canônico de 1983, prevalece o princípio da não passagem em julgado das sentenças relativas ao estado das pessoas (c. 1643). E o mesmo se lê nos diplomas processuais contemporâneos, incluída a Lei n. 13.105/2015 (vide art. 505, I).

\subsection{Era moderna}

Sob as monarquias absolutas, tributárias da visão de que o poder de dizer o justo seria prerrogativa exclusiva do soberano, arrimou-se a ideia de que cabia ao rei ou ao príncipe, em todo caso, dar a palavra final em qualquer matéria litigiosa levada aos tribunais do reino ou principado. Recuperou-se, assim, a noção de recurso - e, por detrás dela, a de direito de recurso (ou do direito ao duplo grau de jurisdição) —, que já tinha lindes relativamente sólidos traçados desde Roma; mas, agora, recuperava-se como forma de subalternizar a jurisprudência à vontade do monarca.

Vale notar que, excetuado o ambiente jurídico-canônico, a inexistência de estruturas hierárquicas claras no mundo feudal inviabilizou, de regra, a afirmação histórica 
dos institutos recursais, "quase desconhecido[s] na Idade Média". ${ }^{13}$ Com a centralização política do Estado moderno, entretanto, a autoridade das jurisdições superiores passou a fazer sentido orgânico. Assim é que, na França, os catorze parlamentos e os quatro conselhos soberanos adquiriram competência para julgar, em grau de recurso, toda a matéria decidida pelas jurisdições territoriais, com raras exceções; de modo semelhante, nas XVII Províncias dos Países Baixos, o Grande Conselho de Malines ("Consilium Magnum”), restabelecido em 1504, passou a julgar, em grau de recurso, todos os casos já decididos pelos conselhos de justiça locais (ressalvados aqueles apreciados pelos conselhos soberanos, porque esses tinham o beneplácito direto do monarca).

$\mathrm{Na}$ mesma linha, os corpos judiciais da era moderna conheceram uma gradual profissionalização a partir do século XIII, e sobretudo entre os séculos XVI e XVIII (logo, em plena Idade Moderna). Originalmente, a justiça feudal era distribuída basicamente por juizes populares, sem formação técnico-jurídica. Bastava ao louvado pertencer ao grupo social que se submetia à jurisdição do respectivo tribunal: os vassalos, nos tribunais feudais; os possuidores tenenciais jurados, nos tribunais censuais; os membros da profissão, nos tribunais dos colégios profissionais ou das corporações de ofício; e assim sucessivamente. Entretanto, desde o século XIIII, os tribunais passaram a contar com juízes profissionais (notadamente nas altas jurisdições reais e dos principados, mas também nos grandes escabinatos), que adquiriam sua formação jurídica nas universidades europeias..$^{14}$ No século XVI, praticamente todos os conselheiros judiciais do continente deviam ser licenciados em Direito; assim, e.g., cite-se o caso do Parlamento de Paris, que tinha, no século XVIII, cerca de duzentos conselheiros e presidentes, todos com formação jurídica universitária. Surge aí, segundo Gilissen, a figura do "juiz-jurista”, que contribuiria decisivamente para a romanização dos direitos nacionais. ${ }^{15}$ Cremos, porém, haver aí outros dois contributos para os pósteros: (a) a suposição de que a formação de corpos de juízes profissionais assegura decisões mais previsíveis e ortodoxas, sem grandes desvios em relação à vontade original do príncipe (ou do parlamento, por delegação daquele; ou da lei, por obra do último); e (b) o reconhecimento da formação técnicoprofissional como uma garantia de soluções seguras, justas e conformes ao Direito. A primeira ideia ainda faz sentido em círculos positivistas, mas está em franco declínio.

13 GILISSEN, John. Introdução histórica ao direito. Trad. A. M. Hespanha, L. M. Macaísta Malheiros. Lisboa: Fundação Calouste Gulbenkian, 1988. p. 394.

14 Que, nos primórdios, ensinavam basicamente os direitos romano e canônico. Quem se formava em tais cursos era chamado de "doctor utriusque iuris" (= doutor em ambos os direitos). V. GILISSEN, John. Introdução histórica ao direito. Trad. A. M. Hespanha, L. M. Macaísta Malheiros. Lisboa: Fundação Calouste Gulbenkian, 1988. p. 149 e 342-356.

15 GILISSEN, John. Introdução histórica ao direito. Trad. A. M. Hespanha, L. M. Macaísta Malheiros. Lisboa: Fundação Calouste Gulbenkian, 1988. p. 390-391. 
Já a derradeira contribuição informa grandemente os modelos judiciais contemporâneos, em especial nos países de tradição romano-germânica, nos quais o acesso aos quadros da magistratura pressupõe aprovação em rigorosos concursos de provas e títulos (mas, ainda assim, com exceções, como se vê, p.ex., no instituto do tribunal de júri ou na figura dos juízes leigos $\left.{ }^{16}\right)$.

Remonta, portanto, à formação do Estado moderno a concepção acabada do direito de recurso como um corolário do direito de defesa (e, portanto, como uma dimensão do "procedural due process"). E, mais, o entendimento de que a decisão jurídica e a sua revisão, com a oficialidade do Estado moderno, pressupõem profissionalidade.

Da jusfundamentalidade do direito de revisão das decisões judiciais — que é outra questão - , passamos a tratar em seguida. Com a devida cautela.

2. O direito de recorrer e a sua condição de jusfundamentalidade no mundo contemporâneo. Uma leitura crítica

Nos sistemas jurídicos contemporâneos - em que as Constituições ditam a semântica fundamental de validade de tudo aquilo que, no plano jurídico, herda-se ou se cria - , todo o legado oriundo do lento processo histórico descrito acima põe-se em xeque com a formulação de uma pergunta básica: toda pessoa tem assegurado, como um seu direito humano fundamental, o de obter a revisão das sentenças judiciais regularmente prolatadas? Ou, analiticamente (o que é o mesmo): toda pessoa que tem suas pretensões materiais apreciadas e julgadas por um órgão jurisdicional, como resultado final de uma sequência concatenada de atos formais (= procedimento) realizada sob contraditório e informada por uma teia de relações jurídicas de natureza pública (= processo), tem direito a ver o seu caso reapreciado por um segundo órgão jurisdicional?

Eis, na verdade, o que inexoravelmente se embute na afirmação de que o "acesso ao duplo grau de jurisdição" seja um predicamento inerente ao devido processo formal jurisdicional ("procedural due process").

E nem sempre será. Vejamos.

O tema talvez seja mais ruidoso no Brasil do que em outros países da região, ou mesmo na Europa — onde a garantia sequer é enunciada, nesses termos, para típicas questões cíveis - , porque o duplo grau de jurisdição foi, no passado, uma garantia constitucional semiexpressa, conectada ao devido processo formal em toda e qualquer

16 Que ainda existem em inúmeros sistemas jurídicos nacionais. Para citar apenas três exemplos, pense-se nos conseils de prod'hommes franceses, nas representações classistas dos tribunais trabalhistas alemães e nos escabinatos militares brasileiros. 
jurisdição (cível ou criminal). Com efeito, dispunha o art. 158 da Constituição do Império (1824):

Art. 158. Para julgar as Causas em segunda, e ultima instancia haverá nas Províncias do Imperito as Relações, que forem necessárias para comodidade dos Povos.

Era, aliás, a origem constitucional dos tribunais de apelação, depois tribunais de justiça dos Estados-membros da Federação. Todas as constituições brasileiras ulteriores, porém, silenciaram sobre o julgamento das causas em segunda instância. Referiam apenas a existência dos tribunais e as suas funções eminentemente revisoras (a designação "tribunal”, portanto, passou a se destinar apenas aos órgãos jurisdicionais colegiados com competência recursal, ${ }^{17}$ diversamente do que se dá em Portugal, p. ex.); mas, como a função revisora implica a existência de recursos, muitos autores seguiram extraindo desses preceitos um suposto princípio "implícito” do duplo grau de jurisdição.

É o que se dá, hoje, com o art. 92 da CRFB, que prevê a existência de juízes federais $e$ tribunais regionais federais, juízes do trabalho $e$ tribunais regionais do trabalho, juízes militares $e$ tribunais militares, além de juízes $e$ tribunais dos Estados, do Distrito Federal e dos Territórios (que já não existem mais). Há quem entenda que, por estabelecer essa estrutura judiciária, a ordem jurídica constitucional brasileira plantou um princípio não expresso de recorribilidade (logo, de duplo grau de jurisdição) incindível de sua própria positividade e historicidade.

Com todas as vênias, o argumento é débil.

A Constituição brasileira também prevê a existência de tribunais superiores (art. 92, I e II, art. 111, I, art. 118, I, art. 122, I), mas está fora de dúvidas que a jurisdição revisional extraordinária não existe para todos os casos. Sendo assim, não há razões para que os tribunais ordinários, ditos de segundo grau, possam ser irrestritamente acionados, qual panaceia para um voto silencioso de desconfiança contra as magistraturas de piso. Ao contrário, há mesmo uma tendência contemporânea de se prestigiar as decisões de primeiro grau — cujas razões históricas já articulamos acima — e limitar sensivelmente

\footnotetext{
17 O que hodiernamente sequer é tão exato. O sistema processual brasileiro passou a conviver, por força do art. 98, I, in fine, da CRFB e depois do art. 41, $\S 1^{\circ}$, da Lei n. 9.099/95, com as chamadas turmas recursais, destinadas a decidir os recursos interpostos contra decisões dos juizados especiais cíveis e criminais (que julgam causas de pequena alçada e questões civis de baixa complexidade, a esfera cível, e infrações penais de menor potencial ofensivo, na esfera penal). Nos termos da lei, essas turmas são formadas por três juízes togados em exercício no primeiro grau de jurisdição e a elas não se reserva a denominação de "tribunais". Logo, são órgãos colegiados com competência recursal, mas não são "tribunais" (até porque seus integrantes ainda não foram promovidos ao segundo grau de jurisdição). Daí porque, hoje, a expressão — e as distinções que encerra — talvez faça mais sentido na perspectiva das carreiras da Magistratura do que na perspectiva estritamente funcional.
} 
o acesso ao segundo grau de jurisdição, a bem inclusive do princípio da duração razoável do processo (art. $5^{\circ}$, LXXVIII).

Não fosse assim, ao revés, seriam "constitucionalmente suspeitas" para utilizar a célebre expressão de Roe v. Wade - normas como a do art. $893, \S 1^{\circ}$, da CLT, que prevê a irrecorribilidade das decisões interlocutórias no processo do trabalho (interlocutórias que podem inclusive ser de mérito, a ponto de configurarem sentenças parciais, como passa a admitir o Novo Código de Processo Civil ${ }^{18}$ ); ou a do art. 899, $\S 1^{\circ}$, do mesmo diploma, que prevê o ônus processual de recolhimento do valor da condenação, até certo limite, como condição para a admissibilidade do recurso ordinário trabalhista (ambas jamais contestadas seriamente); ou a do art. 34 da Lei n. 6.830/80 (Lei de Executivos Fiscais); ou, ainda, a do art. 518, $\S 1^{\circ}$, do CPC/1973, introduzido pela Lei n. 11.276/2006, segundo o qual “o juiz não receberá o recurso de apelação quando a sentença estiver em conformidade com súmula do Supremo Tribunal de Justiça ou do Supremo Tribunal Federal" (esse efetivamente contestado, mas sobretudo por razões outras - como a criação de "súmulas vinculantes de segundo nível" carentes de previsão constitucional ${ }^{19}$ - que não a violação de um suposto princípio de duplo grau de jurisdição), agora potenciada sob o NCPC (v., p. ex., o art. 496, § $4^{\text {o }}{ }^{20}$ ).

Tais preceitos são constitucionais e parecem compreender-se dentro da esfera de conformação legislativa do devido processo formal. Ademais, a própria Constituição de 1988 evidenciou, em ao menos duas passagens, a virtual possibilidade de existirem decisões - e, mais que decisões, sentenças - irrecorríveis: ao tratar das

18 V., e.g., o art. 356 da Lei n. 13.105/2015: "O juiz decidirá parcialmente o mérito quando um ou mais dos pedidos formulados ou parcela deles: $\boldsymbol{I}$ - mostrar-se incontroverso; II - estiver em condições de imediato julgamento, nos termos do art. 355. $\$ 1^{\circ}$ A decisão que julgar parcialmente o mérito poderá reconhecer a existência de obrigação líquida ou ilíquida. $\$ 2^{\circ}$ A parte poderá liquidar ou executar, desde logo, a obrigação reconhecida na decisão que julgar parcialmente o mérito, independentemente de caução, ainda que haja recurso contra essa interposto. $\S 3^{\circ} \mathrm{Na}$ hipótese do $\S 2^{\circ}$, se houver trânsito em julgado da decisão, a execução será definitiva. $\$ 4^{\circ}$ A liquidação e o cumprimento da decisão que julgar parcialmente o mérito poderão ser processados em autos suplementares, a requerimento da parte ou a critério do juiz. $\S \mathbf{5}^{\circ} \mathrm{A}$ decisão proferida com base neste artigo é impugnável por agravo de instrumento".

19 V., e.g., STRECK, Lenio Luiz. A "repercussão geral das questões constitucionais" e a admissibilidade do recurso extraordinário: preocupação do constituinte com as "causas irrelevantes". In: AGRA, Walber de Moura (Coord.). Comentários à reforma do poder judiciário. Rio de Janeiro: Forense, 2005. p. 132-142. p. 137. De nossa parte, reputamo-lo constitucional; v. FELICIANO, Guilherme Guimarães. O 'novíssimo' processo civil e o processo do trabalho: uma outra visão. Revista de Direito do Trabalho, São Paulo, v. 33. n. 125 , p. $46-87,2007$. n. V.

20 " $\$ 4^{\circ}$ Também não se aplica o disposto neste artigo [duplo grau de jurisdição] quando a sentença estiver fundada em: I - súmula de tribunal superior; II - acórdão proferido pelo Supremo Tribunal Federal ou pelo Superior Tribunal de Justiça em julgamento de recursos repetitivos; III - entendimento firmado em incidente de resolução de demandas repetitivas ou de assunção de competência; $\boldsymbol{I V}$ - entendimento coincidente com orientação vinculante firmada no âmbito administrativo do próprio ente público, consolidada em manifestação, parecer ou súmula administrativa." 
competências do Supremo Tribunal Federal (art. 102) e do Superior Tribunal de Justiça (art. 1005), dispõe competir ao primeiro:

III - julgar, mediante recurso extraordinário, as causas decididas em única ou última instância, quando a decisão recorrida: $[\ldots](g . n$.$) ;$

E ao segundo:

III - julgar, em recurso especial, as causas decididas, em única ou última instância, pelos Tribunais Regionais Federais ou pelos tribunais dos Estados, do Distrito Federal e Territórios, quando a decisão recorrida: $[\ldots](g . n$.);

Logo, é cediço que o sistema processual constitucionalmente delimitado admite a existência de sentenças de única instância. E não se queira dizer, por forçado, que tais referências constitucionais digam com a hipótese absolutamente esdrúxula de julgados em que tenham transitado em primeiro grau (ações comuns) ou em segundo grau (ações originárias) por decurso de prazo... ${ }^{21}$

No âmbito do Direito Internacional Público, alguma dúvida poderia advir da tradução amiúde utilizada, nos países lusófonos, para a Declaração Universal dos Direitos Humanos (DUDH), de 1948. É que, quanto às garantias processuais em geral, dispõe o art. $8^{\circ}$ da DUDH:

Artigo $\mathbf{8}^{\mathbf{0}}$. Toda pessoa tem direito a recurso efetivo para os tribunais nacionais competentes contra os atos que violem os direitos fundamentais que lhe sejam reconhecidos pela Constituição ou pela lei. $(g . n$.)

Já quanto às garantias do devido processo penal, dispõe o art. 11:

Artigo 11. 1. Toda pessoa acusada de um ato delituoso tem o direito de ser presumida inocente até que a sua culpabilidade tenha sido provada de acordo com a lei, em

${ }_{21}$ Tese interessante e inclusive defensável, a meio caminho de uma e outra ideia, é a de DINAMARCO, Cândido Rangel. Instituições de direito processual civil. São Paulo: Malheiros Editores, 2001. v. 1. p. 195, que reconhece no duplo grau de jurisdição um princípio geral (mesmo no processo civil), mas não uma garantia: "Caso isolado de princípio constitucional endereçado ao processo e desprovido do caráter de imperatividade é o do chamado princípio do duplo grau de jurisdição. $\boldsymbol{E}$ um princípio sim e, como tal, há de inspirar o legislador ao editar leis e o juiz ao interpretá-las e resolver os casos de dúvida sobre a concreta admissibilidade de algum recurso. Não é uma garantia, porém, dado que a própria Constituição apresenta hipóteses de grau único de jurisdição (p. ex., em certos casos de competência originária dos tribunais, em que é excepcional a recorribilidade dos julgados" ( $g$. n.). Seria, portanto, o único caso de princípio constitucional de processo a não se revestir da condição de garantia processual. Difícil compreender, porém, como o legislador ordinário poderia “se inspirar” no princípio e ao mesmo tempo ignorá-lo, à mercê de seu poder de conformação. A vingar tal tese, afetar-se-ia ao cabo e ao fim apenas a atividade do juiz, com um curioso princípio hermenêutico tendencial do tipo "in dubio pro recursus". 
julgamento público no qual lhe tenham sido asseguradas todas as garantias necessárias à sua defesa. [...].

Dadas essas bases, porém, impende tecer alguns esclarecimentos.

A garantia do art. $8^{\circ}$ da DUDH assegura, ao mesmo tempo, o acesso à justiça e a efetividade da jurisdição ("recours effectif", "effective remedy": remédio efetivo, a rigor, seria uma tradução mais feliz); não, como pareceria ao leitor incauto, um "direito universal de recorrer". "Tribunais" ou "jurisdições nacionais competentes", ademais, sequer significam necessariamente órgãos jurisdicionais clássicos (i.e., propriamente judiciais, vinculados à organização judiciária do país), mas indicam órgãos públicos que materialmente exerçam funções tipicamente jurisdicionais. ${ }^{22}$ Com toda razão, a doutrina contemporânea tem assentado que a jurisdição, mais do que a atuação da vontade concreta da lei (Chiovenda), é uma função de tutela de direitos. Com efeito,

a norma constitucional que afirma a ação [art. $5^{\circ}, \mathrm{XXXV}$, $\mathrm{CRFB}$ ] institui o direito fundamental à tutela jurisdicional efetiva, e, dessa forma, confere a devida oportunidade da prática de atos capazes de influir sobre o convencimento judicial, assim como a possibilidade do uso das técnicas processuais adequadas à situação conflitiva concreta. [...] O direito fundamental à tutela jurisdicional efetiva obriga $o$ juiz a garantir todos os seus corolários, como o direito ao meio executivo capaz de permitir a tutela do direito, além de obrigar o legislador a desenhar os procedimentos e as técnicas processuais adequadas às diferentes situações de direito substancial. ${ }^{23}(g . n$.)

A “justiça de papel”, cujos resultados concretos tardam ou não chegam (em especial quando se trata de obstar ou fazer cessar agressões a direitos fundamentais, como é o caso), não serve para os presentes tempos. Há décadas (1921), antes da própria DUDH, o grande brasileiro Rui Barbosa bem sintetizou essa nova e velha necessidade:

Mas justiça atrasada não é justiça, senão injustiça qualificada e manifesta. Porque a dilação ilegal nas mãos do julgador contraria o direito escrito das partes, e, assim, as lesa no patrimônio, honra e liberdade. Os juízes tardinheiros são culpados, que a lassidão comum vai tolerando. Mas sua

22 Cf. MARTINS, Ana Maria Guerra. Direito internacional dos direitos humanos. Coimbra: Almedina, 2006. p. 170. Um exemplo de órgão não judicial com funções jurisdicionais seria, no Brasil, o Tribunal Especial previsto na Constituição do Estado de São Paulo (art. 49) para o julgamento dos crimes de responsabilidade do Governador do Estado, que está impugnado (ADI n. 2220-2), mas seria composto por sete deputados estaduais e sete desembargadores do Tribunal de Justiça de São Paulo, sob a tutela do Presidente do Tribunal de Justiça; ou ainda, nas monarquias que o admitem, a própria Coroa.

23 MARINONI, Luiz Guilherme. Teoria geral do processo. 3. ed., rev. e atual. São Paulo: Revista dos Tribunais, 2008. v. 1. p. 285-291. 
culpa tresdobra com a terrível agravante de que o lesado não tem meio de reagir contra o delinqüente poderoso, em cujas mãos jaz a sorte do litígio pendente.

Não sejais, pois, desses magistrados, nas mãos de quem os autos penam como as almas do purgatório, ou arrastam sonos esquecidos como as preguiças do mato. ${ }^{24}$

A exortação segue verdadeira nos dias de hoje. E soa especialmente valiosa e atual, se considerarmos — com Marinoni e outros — que "justiça" não é a sentença prolatada, mas é o bem da vida assegurado à fruição. Essa consideração tem eco no mais importante texto internacional de salvaguarda de direitos humanos, precisamente em seu art. $8^{\circ}$; mas o que se assegura ali, insista-se, é a efetividade da jurisdição, não a "formalidade" do duplo grau de jurisdição.

$\mathrm{O}$ art. 10 da DUDH, por sua vez, assegura o chamado processo equitativo, que se aproxima essencialmente da ideia anglo-saxônica de "procedural due process" e contempla aspectos como a independência dos tribunais e a imparcialidade dos juízes, a isonomia processual, o contraditório e o próprio "direito a um dia na corte" (o "right to a day in court" da tradição anglo-saxônica), ou — mais apropriadamente - o de ser ouvido na corte (a "rechtliches Gehör" do art. 103, 1, da GG, em acepção restritíssima). Essa garantia foi depois repetida e estendida no art. 14, 1, do Pacto Internacional dos Direitos Civis e Políticos (Res. n. 2.200 A(XXI), 16.11.1966), também do sistema ONU. In verbis:

1. Todas as pessoas são iguais perante os tribunais de justiça. Todas as pessoas têm direito a que a sua causa seja ouvida equitativa e publicamente por um tribunal competente, independente e imparcial, estabelecido pela lei, que decidirá quer do bem fundado de qualquer acusação em matéria penal dirigida contra elas, quer das contestações sobre os seus direitos e obrigações de carácter civil. As audições à porta fechada podem ser determinadas durante a totalidade ou uma parte do processo, seja no interesse dos bons costumes, da ordem pública ou da segurança nacional numa sociedade democrática, seja quando o interesse da vida privada das partes em causa o exija, seja ainda na medida em que o tribunal o considerar absolutamente necessário, quando, por motivo das circunstâncias particulares do caso, a publicidade prejudicasse os interesses da justiça; todavia qualquer sentença pronunciada em matéria penal ou civil será publicada, salvo se o interesse de menores exigir que se proceda de outra forma ou se o processo respeita a diferendos matrimoniais ou à tutela de crianças.

${ }_{24}$ BARBOSA, Rui. Oração aos moços. 5. ed. Rio de Janeiro: Casa de Rui Barbosa, 1997. p. 40. 
Identificando no art. 10 da DUDH o direito fundamental a um processo equitativo e buscando dar-lhe desenvolvimentos mais concretos, Guerra Martins ${ }^{25}$ condensa seus consectários, asserindo que

todos são iguais perante os tribunais, tendo direito a que
a sua causa seja ouvida equitativa e publicamente por um
tribunal competente, independente e imparcial, estabelecido
por lei, que decidirá do bem fundado de qualquer "acusação
em matéria penal" e das "contestações sobre direitos e
obrigações em matéria carácter civil".

E disso conclui que, pelo padrão internacional, nem todos os litígios atrairiam a garantia do processo equitativo, mas apenas os processos penais e civis (excluindo-se, $\mathrm{p}$. ex., os processos de natureza administrativo-discricionária, que implicam o exercício do "ius imperii", como são os procedimentos de expulsão de estrangeiros ou de concessão de asilo político). Observa, ademais, a dificuldade de se determinar, nos diversos países, se determinado processo/procedimento configura ou não "acusação em matéria penal" (= DUDH: "acusação criminal”; PIDCP: "matéria penal”) ou "contestações em matéria civil” (= DUDH: “decidir dos seus direitos e deveres”, PIDCP: “matéria civil”). Para esse efeito, o Comitê de Direitos Humanos da ONU (art. $28^{\circ}$ do PIDCP) tem seguido de perto a jurisprudência do Tribunal Europeu dos Direitos Humanos, no sentido de que o conceito de "acusação penal", para os efeitos da DUDH, pressupõe uma notificação oficial emanada de autoridade competente a acusar o indivíduo do cometimento de certa infração de natureza eminentemente penal (afastando-se, portanto, as contraordenações e ilícitos administrativos); já “contestações em matéria civil” implicam processos/procedimentos com objeto e incidência patrimonial, sob qualquer regência legal (civil, trabalhista, comercial, fiscal, administrativa) e perante quaisquer órgãos oficiais (o que inclui não apenas os órgãos judiciais, mas também os administrativos). Isso abrangeria inclusive processos de despedimento da função pública (Comunicação n. 441/90, Casanovas v.

25 MARTINS, Ana Maria Guerra. Direito internacional dos direitos humanos. Coimbra: Almedina, 2006. p. 167-173. 
França, 10.8.1994²6), que também desafiariam as plenas garantias do processo equitativo; mas excluiria processos sobre o estado de pessoais (e.g., interdições civis ${ }^{27}$ ).

Em termos de conteúdo, ademais, o Comitê de Direitos Humanos da ONU tem estendido significativamente a dimensão semântica da garantia do processo equitativo (ex art. $8^{\circ}$ da DUDH), para efetivamente alcançar os seguintes direitos:

(a) o direito de acesso efetivo e concreto a um "tribunal", i.e., a um órgão oficial dotado de jurisdição (Comunicação n. 779/1997, Anni Äärelä, Jouni Näkkäläjärvi v. Finlândia, 7.11.200128);

${ }_{26}$ In verbis: "5.2. The Committee recalled that the concept of 'suit at law' under article 14, paragraph 1, was based on the nature of the right in question rather than on the status of one of the parties. The Committee considered that a procedure concerning a dismissal from employment constituted the determination of rights and obligations in a suit at law, within the meaning of article 14, paragraph 1, of the Covenant. Accordingly, on 7 July 1993, the Committee declared the communication admissible" (CCPR/ C/51/D/441/1990 (1994) [g. n.]). Essa e todas as demais comunicações do Human Rights Committee citadas neste tópico estão disponíveis em: <http://www1.unm.edu/humanrts/undcos>. Acesso em: 18 jan. $2011 \mathrm{e} /$ ou das citações de MARTINS, Ana Maria Guerra. Direito internacional dos direitos humanos. Coimbra: Almedina, 2006. Passim.

27 MARTINS, Ana Maria Guerra. Direito internacional dos direitos humanos. Coimbra: Almedina, 2006. p. 168.

28 No caso concreto, o parecer contrário às posições do Estado-membro (Finlândia) baseou-se no fato de que as elevadas custas exigidas para o acesso à corte de apelação, sem consideração das condições pessoais dos interessados, representou violação ao dever de proporcionar acesso efetivo aos tribunais. In verbis: "3.2. The authors claim a violation of article 14, paragraphs 1 and 2, of the Covenant, contending that the Appeal Court was not impartial, having pre-judged the outcome of the case and violated the principle of equality of arms in (i) allowing oral hearings while denying an on-site inspection and (ii) taking into account material information without providing an opportunity to the other party to comment. The authors also contend that the award of costs against the authors at the appellate level, having succeeded at first instance, represents bias and effectively prevents other Sami from invoking Covenant rights to defend their culture and livelihood. There is no State assistance available to impecunious litigants to satisfy the imposition of costs. [...] 4.11. As to the imposition of costs, the State party points out that under its law there is an obligation for the losing party to pay, when sought, the reasonable legal costs of the successful party. The law does not alter this situation when the parties are a private individual and public authority, or when the case involves human rights issues. These principles are the same in many other States, including Austria, Germany, Norway and Sweden, and are justified as a means of avoiding unnecessary legal proceedings and delays. The State party argues this mechanism, along with free legal aid for lawyers' expenses, ensures equality in the courts between plaintiffs and defendants. The State party notes however that, from 1 June 1999, an amendment to the law will permit a court ex officio to reduce a costs order that would otherwise be manifestly unreasonable or inequitable with regard to the facts resulting in the proceedings, the position of the parties and the significance of the matter. [...] 7.2. As to the authors' argument that the imposition of a substantial award of costs against them at the appellate level violated their rights under article 14, paragraph 1, to equal access to the courts, the Committee considers that a rigid duty under law to award costs to a winning party may have a deterrent effect on the ability of persons who allege their rights under the Covenant have been violated to pursue a remedy before the courts. In the particular case, the Committee notes that the authors were private individuals bringing a case alleging breaches of their rights under article 27 of the Covenant. In the circumstances, the Committee considers that the imposition by the Court of Appeal of substantial costs award, without the discretion to consider its implications for the particular authors, or its effect on access to court of other similarly situated claimants, constitutes a violation of the authors' rights under article 14, paragraph 1, in conjunction with article 2 of the Covenant. The Committee notes that, in the light of the relevant amendments to the law governing judicial 
(b) a paridade de armas (Comunicação n. 846/1999, Jansen-Gielen v. Países Baixos, 14.5.2001);

(c) as garantias relativas à organização e à composição dos tribunais - que devem ser imparciais e instituídos "ex ante facto" - e ao desenvolvimento do processo - o que inclui a sua duração razoável (Comunicação n. 387/1989, Arvo Karttunen v. Finlândia, 15.11.1992; Comunicação n. 207/1986, Morael v. França, 28.7.1989);

(d) as garantias específicas do devido processo penal.

O duplo grau de jurisdição, a rigor, é inerente apenas a essa última linha de direitos-garantais. E somente a ela.

Por tais razões e outras tantas, o entendimento cada vez mais dominante é o de que o duplo grau de jurisdição já não é uma garantia inerente ao devido processo legal procedimental em matéria cível, ao menos no Brasil (e, ao que consta, tal é a regra fora dele). Entre nós, é irretocável a assertiva de Nery Jr.:29

[...] não havendo garantia constitucional do duplo grau, mas mera previsão, o legislador infraconstitucional pode limitar o direito de recurso, dizendo, por exemplo, não caber apelação nas execuções fiscais de valor igual ou inferior a 50 OTNs (art. 34, da Lei n. 6.830/80) e nas causas, de qualquer natureza, nas mesmas condições, que forem julgadas pela Justiça Federal (art. $4^{\circ}$, da Lei n. 6.825/80), ou, ainda, não caber recurso dos despachos (art. 504, CPC). [...] Esses artigos não são inconstitucionais justamente em face da ausência de 'garantia' do duplo grau de jurisdição. Entretanto, não poderá haver limitação ao cabimento do recurso especial ou extraordinário, como era permitido no sistema revogado (art. 119, $\S 1^{\circ}, \mathrm{CF}$ de 1969), porque a atual Constituição Federal não estipulou nenhuma restrição. Os requisitos estão no próprio texto constitucional e somente eles devem ser exigidos do recorrente para que sejam conhecidos os recursos extraordinário e especial.

Já não é assim, porém, em matéria processual penal, na própria interpretação da DUDH. Nessa hipótese, entende-se que o duplo grau de jurisdição é uma garantia ínsita ao devido processo penal, por força do Direito Internacional dos Direitos Humanos.

procedure in 1999, the State party's courts now possess the discretion to consider these elements on a case by case basis.[...]”. (CCPR/C/73/D/779/1997 [g. n.]).

29 NERY JUNIOR, Nelson. Princípios do processo civil na constituição federal. 5. ed., rev. e ampl. São Paulo: Revista dos Tribunais, 1999. p. 211-212. 
Com efeito, o direito a um recurso contra sentenças penais condenatórias não apenas decorre do art. 11 da DUDH, como também está explicitamente descrito no art. 14, 1 e 5, do Pacto Internacional dos Direitos Civis e Políticos (1966), parcialmente reproduzido acima; e, entre nós, no art. $8^{\circ}, 2$, “ $h$ ”, do Pacto de San José da Costa Rica (que assegura, apenas em matéria penal, o "direito de recorrer da sentença a juiz ou tribunal superior”'). Já não há semelhante previsão, por exemplo, no art. $6^{\circ}$ da Convenção Europeia dos Direitos do Homem ou nos arts. 47 a 50 da Carta dos Direitos Fundamentais da União Europeia. Como se trata, porém, de uma previsão ínsita ao próprio PIDCP ( "Qualquer pessoa declarada culpada de crime terá o direito de fazer examinar por uma jurisdição superior a declaração de culpabilidade e a sentença, em conformidade com a $\left.l e i{ }^{\prime 30}\right)$, parece claro que todos os países que tenham assinado o Pacto ${ }^{31}$ introduziram ou comprometeram-se a introduzir, em seus respectivos ordenamentos internos, a garantia do duplo grau de jurisdição penal. Inclusive os europeus.

Nesse caso, a garantia do duplo grau de jurisdição penal tanto deve alcançar as sentenças condenatórias típicas como - onde houver - as sentenças absolutórias impróprias (i.e., sentenças penais que impõem medidas de segurança ou outras constrições com base na periculosidade do réu, não em sua culpabilidade). O recurso, ademais, deve ser um meio processual capaz de oferecer nova oportunidade para a defesa, com a rediscussão dos fatos, das provas e do direito aplicado, assegurando o controle da legalidade e da razoabilidade/proporcionalidade da sentença (v., e.g., Corte Interamericana dos Direitos Humanos, Informe n. 17/94 e 55/97). Não basta que seja um mero acesso formal e burocrático a órgão distinto, sem possibilidades reais de efetiva mutação da sentença “a quo”; nem tampouco podem estar presentes restrições legais que aniquilem

30 Observe-se que tanto o PSJCR quanto o PIDCP utilizam a expressão "delito" (nesta última, em inglês, “crime”). A palavra não é unívoca e chega mesmo a ser utilizada, em alguns sistemas (como no Brasil), como sinônimo de crime (i.e., designariam a classe de infrações penais de maior gravidade no ordenamento, excluindo-se as de menor intensidade, como as contravenções); noutros sistemas, porém, pode designar uma classe de infrações penais de média intensidade (como são os "délits" na França, que não se confundem com os “crimes", mais graves, ou com as "contraventions”, menos graves — v. art. 111-1 do Code pénal francês). Não haveria sentido, porém, em se garantir o duplo grau de jurisdição nas condenações por infrações penais menos graves ("délits") e apenas facultá-lo nas condenações por infrações penais mais graves ("crimes"). Assim, para se evitar dificuldades e resolver o dilema hermenêutico de acordo com os princípios que devem reger a interpretação das fontes de direitos humanos fundamentais - em especial o princípio da máxima efetividade - , acreditamos que a garantia do duplo grau de jurisdição penal do PIDCP deva se estender, nos países que o ratificarem ou a ele aderirem, a todas as espécies de infrações penais (das mais graves às mais leves). Ademais, como já se viu, mesmo infrações administrativas de maior gravidade - como são aquelas contravenções que perderam a natureza penal nas reformas legislativas das últimas décadas - tem sido incluídas sob a proteção do devido processo penal, inclusive no âmbito europeu.

31 O PIDCP não prevê mecanismos de reservas, diversamente da CEDH, que dispôs, em seu art. 57, 1, sobre a possibilidade de reservas ao tempo da ratificação, apenas no caso de haver, no território do Estado, lei em vigor contrária a alguma de suas disposições. 
ou comprometam grandemente a própria essência do duplo grau de jurisdição (v., e.g., Corte Interamericana dos Direitos Humanos, Herrera Ulloa v. Costa Rica, 2.7.2004 ${ }^{32}$ ).

Mesmo no plano processual penal, porém, divisam-se duas exceções para o duplo grau de jurisdição (uma de ordem lógica e outra de ordem sistêmica, respectivamente):

(a) a condenação penal imposta pelo tribunal máximo do país (e.g., no Brasil, a condenação criminal do Presidente e do Vice-Presidente da República, dos ministros de Estado, do Procurador-Geral da República, dos deputados federais e dos senadores da República, que respondem todos, por infrações penais comuns, perante o Supremo Tribunal Federal, ex art. 102, I, “b”, da CRFB); e

(b) a condenação imposta em razão de recurso da acusação contra sentença absolutória (porque, de todo modo, terá havido dupla apreciação do caso "in $\left.s e^{\prime \prime}\right){ }^{33}$

Diga-se, ademais, que o fato de, no Brasil, as condenações dos juizados especiais criminais (art. 98, I, da CRFB) serem objeto de revisão por turmas recursais de juízes de primeiro grau não compromete a garantia do duplo grau. Como registrou L. F. Gomes, no contexto do PSJCR,

O recurso [...] deve ser interposto para 'juiz ou tribunal superior'. Não se trata necessariamente de um órgão superior hierárquico, basta que seja um juiz ou tribunal distinto, que conte com as faculdades de revisar os fatos, provas e direito objeto da sentença recorrida. ${ }^{34}$

32 In verbis: “[...] 163. El juez o tribunal superior encargado de resolver el recurso interpuesto contra la sentencia penal tiene el deber especial de protección de las garantías judiciales y el debido proceso a todas las partes que intervienen en el proceso penal de conformidad con los principios que lo rigen. [...] 164. La posibilidad de 'recurrir del fallo' debe ser accesible, sin requerir mayores complejidades que tornen ilusorio este derecho. [...] 166. Al respecto, el Comité de Derechos Humanos concluyó '[...] que la inexistencia de la posibilidad de que el fallo condenatorio y la pena del autor fueran revisadas integramente, como se desprende de la propia sentencia de casación [...], limitándose dicha revisión a los aspectos formales o legales de la sentencia, no cumbre con las garantías que exige el párrafo 5 , artículo 14 del Pacto. Por consiguiente, al autor le fue denegado el derecho a la revisión del fallo condenatorio y de la pena, en violación del párrafo 5 del artículo 14 del Pacto” (g. n.).

33 Cf. JUGO, Gabriela. El derecho de recurrir la sentencia penal condenatoria y los instrumentos internacionales de derechos humanos. In: García, Luis M. (Coord.) Los derechos humanos en el proceso penal. Buenos Aires: Ábaco, 2002. p. 290; cf. também GOMES, Luís Flávio. MAZZUOLI, Valerio de Oliveira. Comentários à Convenção Americana sobre Direitos Humanos: Pacto de San José da Costa Rica. 2. ed. rev., atualizada e ampliada. São Paulo: Revista dos Tribunais, 2009. p. 120. Tais exceções são, na verdade, aquelas mesmas do art. $2^{\circ}$ do Protocolo CEDH n. 7, que inspiraram esta doutrina.

34 GOMES, Luís Flávio. MAZZUOLI, Valerio de Oliveira. Comentários à Convenção Americana sobre Direitos Humanos: Pacto de San José da Costa Rica. 2. ed. rev., atualizada e ampliada. São Paulo: Revista dos Tribunais, 2009. p. 119. 
3. À guisa de conclusão

Ante o exposto, assim delimitaremos, na perspectiva jusfundamental, o alcance recursal imanente ao chamado "procedural due process" (devido processo formal) no Estado Democrático de Direito - e o enunciaremos com pretensões de universalidade, considerando a tessitura contemporânea dos textos legais que compõem o Direito Internacional dos Direitos Humanos -

(a) no plano cível "lato sensu” — e, portanto, no plano trabalhista —, não há garantias necessárias de recorribilidade - o que significa que a matéria estará invariavelmente nos domínios do poder de conformação do legislador ordinário, se não houver previsão específica em sentido diverso nos textos constitucionais;

(b) na esfera criminal, ao contrário, o princípio do duplo grau de jurisdição é uma garantia imanente ao conceito de devido processo legal formal (penal);

(c) consequentemente, não há quaisquer objeções constitucionais, no Brasil, a que se encetem, na legislação processual trabalhista (e nomeadamente no Decreto-Lei n. 5.452/1943 - Consolidação das Leis do Trabalho), reformas de base que reduzam significativamente o papel revisional dos tribunais regionais do trabalho, notadamente no que atine às questões de fato.

Que venha, para logo, um novo processo do trabalho; e que se faça adequado a uma nova visão de mundo. Que saiba recolher, dos modernos, a boa ciência; e, dos antigos, a simplicidade das soluções desburocratizadas e desperenizadas. Tendo, na base, a confiança institucional na primeira autoridade a conhecer da causa.

São Paulo, janeiro de 2016.

Referências

ALVES, José Carlos Moreira. Direito romano. 7. ed. Rio de Janeiro: Forense, 1991. v. 1.

BARBOSA, Rui. Oração aos moços. 5. ed. Rio de Janeiro: Casa de Rui Barbosa, 1997.

CINTRA, Antônio Carlos de Araújo; GRINOVER, Ada Pellegrini; DINAMARCO, Cândido Rangel. Teoria geral do processo. 3. ed. rev. e atual. São Paulo: Malheiros, 1993.

DINAMARCO, Cândido Rangel. Instituições de direito processual civil. São Paulo: Malheiros Editores, 2001. v. 1.

FELICIANO, Guilherme Guimarães. Eficácia mandamental da sentença declaratória de vínculo empregatício em face do Instituto Nacional do Seguro Social. In: $14^{\circ}$ Congresso Nacional dos 
Magistrados da Justiça do Trabalho: CONAMAT, Manaus, 2008. Disponível em: <http://www. conamat.com.br/teses/10032008204910.doc>. Acesso em: 6 jan. 2016.

. O 'novíssimo' processo civil e o processo do trabalho: uma outra visão. Revista de Direito do Trabalho, São Paulo, v. 33. n. 125, p. 46-87, 2007.

. Tutela processual dos direitos humanos nas relações de trabalho. Revista de Direito do Trabalho, São Paulo, v. 32. n. 121, p. 1-2, 2006.

GILISSEN, John. Introdução histórica ao direito. Trad. A. M. Hespanha, L. M. Macaísta Malheiros. Lisboa: Fundação Calouste Gulbenkian, 1988.

GOMES, Luís Flávio. MAZZUOLI, Valerio de Oliveira. Comentários à Convenção Americana sobre Direitos Humanos: Pacto de San José da Costa Rica. 2. ed. rev., atualizada e ampliada. São Paulo: Revista dos Tribunais, 2009.

JUGO, Gabriela. El derecho de recurrir la sentencia penal condenatoria y los instrumentos internacionales de derechos humanos. In: García, Luis M. (Coord.) Los derechos humanos en el proceso penal. Buenos Aires: Ábaco, 2002.

KASER, Max; HACKL, Karl. Das Römische Zivilprozessrecht. 2. Aufl. München: C. H. Beck, 1996.

MARINONI, Luiz Guilherme. Teoria geral do processo. 3. ed., rev. e atual. São Paulo: Revista dos Tribunais, 2008. v. 1.

MARTINS, Ana Maria Guerra. Direito internacional dos direitos humanos. Coimbra: Almedina, 2006.

MENDES, João de Castro. Direito processual civil. Lisboa: AAFDL, 1987. v. 2.

NERY JUNIOR, Nelson. Princípios do processo civil na constituição federal. 5. ed., rev. e ampl. São Paulo: Revista dos Tribunais, 1999.

STRECK, Lenio Luiz. A "repercussão geral das questões constitucionais" e a admissibilidade do recurso extraordinário: preocupação do constituinte com as "causas irrelevantes". In: AGRA, Walber de Moura (Coord.). Comentários à reforma do poder judiciário. Rio de Janeiro: Forense, 2005. p. 132-142.

TUCCI, José Rogério Cruz e; AZEVEDO, Luiz Carlos de. Lições de história do processo civil romano. São Paulo: Revista dos Tribunais, 2001. 
